\title{
The engineered, cytosolic form of human type I $3 \beta$-hydroxysteroid dehydrogenase/isomerase: purification, characterization and crystallization
}

\section{J L Thomas, J I Mason ${ }^{1}$, G Blanco ${ }^{2}$ and M L Veisaga ${ }^{3}$}

Division of Basic Medical Sciences, Mercer University School of Medicine, Macon, Georgia, USA

${ }^{1}$ Department of Reproductive and Developmental Sciences (Clinical Biochemistry), University of Edinburgh, Royal Infirmary of Edinburgh, Edinburgh, UK

${ }^{2}$ Department of Cell Biology and Physiology, Washington University School of Medicine, St Louis, Missouri, USA

${ }^{3}$ Department of Biochemistry and Molecular Biophysics, Washington University School of Medicine, St Louis, Missouri, USA

(Requests for offprints should be addressed to J L Thomas, Division of Basic Medical Sciences, 1550 College Street, Mercer University School of Medicine, Macon, Georgia 31207, USA)

\begin{abstract}
Human type I 3 $\beta$-hydroxysteroid dehydrogenase/ isomerase $(3 \beta-\mathrm{HSD} /$ isomerase) is an integral membrane protein of human placental trophoblast and of insect Sf9 cells transfected with recombinant baculovirus containing the cDNA encoding the enzyme. Purified native or wild-type enzyme remains in solution only in the presence of detergent that may prevent crystallization. The membranespanning domain (residues 283-310) of the enzyme protein was deleted in the cDNA using PCR-based mutagenesis. The modified enzyme was expressed by baculovirus in the cytosol instead of in the microsomes and mitochondria of the Sf9 cells. The cytosolic form of $3 \beta-\mathrm{HSD} /$ isomerase was purified using affinity chromatography with Cibacron Blue 1000. The $\mathrm{NAD}^{+}$and $\mathrm{NaCl}$ used to elute the enzyme were removed by size-exclusion centrifugation. Hydroxylapatite chromatography yielded a 26-fold purification of the enzyme. SDS-PAGE revealed a single protein band for the purified cytosolic enzyme (monomeric molecular mass $38.8 \mathrm{kDa}$ ) that migrated just below the wild-type enzyme (monomeric molecular mass $42.0 \mathrm{kDa}$ ). Michaelis-Menten constants measured for $3 \beta$-HSD substrate (dehydroepiandrosterone) utilization by
\end{abstract}

the purified cytosolic enzyme $\left(K_{\mathrm{m}}=4 \cdot 5 \mu \mathrm{M}\right.$, $\mathrm{V}_{\max }=53 \mathrm{nmol} / \mathrm{min}$ per $\mathrm{mg}$ ) and the pure wild-type enzyme $\left(K_{\mathrm{m}}=3.7 \mu \mathrm{M}, \mathrm{V}_{\max }=43 \mathrm{nmol} / \mathrm{min}\right.$ per $\left.\mathrm{mg}\right)$, for isomerase substrate (5-androstene-3,17-dione) conversion by the purified cytosolic $\left(K_{\mathrm{m}}=25 \mu \mathrm{M}\right.$, $\mathrm{V}_{\max }=576 \mathrm{nmol} / \mathrm{min}$ per $\mathrm{mg}$ ) and wild-type $\left(K_{\mathrm{m}}=28 \mu \mathrm{M}, \mathrm{V}_{\max }=598 \mathrm{nmol} / \mathrm{min}\right.$ per $\left.\mathrm{mg}\right)$ enzymes, and for $\mathrm{NAD}^{+}$reduction by the $3 \beta-\mathrm{HSD}$ activities of the cytosolic $\left(K_{\mathrm{m}}=35 \mu \mathrm{M}, \mathrm{V}_{\max }=51 \mathrm{nmol} / \mathrm{min}\right.$ per $\mathrm{mg})$ and wild-type $\left(K_{\mathrm{m}}=34 \mu \mathrm{M}\right.$, $\mathrm{V}_{\max }=46 \mathrm{nmol} / \mathrm{min}$ per $\mathrm{mg}$ ) enzymes are nearly identical. The isomerase activity of the cytosolic enzyme requires allosteric activation by NADH $\left(K_{\mathrm{m}}=4.6 \mu \mathrm{M}, \quad \mathrm{V}_{\max }=538 \mathrm{nmol} / \mathrm{min}\right.$ per $\left.\mathrm{mg}\right)$ just like the wild-type enzyme $\left(K_{\mathrm{m}}=4.6 \mu \mathrm{M}\right.$, $\mathrm{V}_{\max }=536 \mathrm{nmol} / \mathrm{min}$ per $\mathrm{mg}$ ). Crystals of the purified, cytosolic enzyme protein have been obtained. The inability to crystallize the detergentsolubilized, wild-type microsomal enzyme has been overcome by engineering a cytosolic form of this protein. Determining the tertiary structure of $3 \beta-H S D /$ isomerase will clarify the mechanistic roles of potentially critical amino acids ( $\mathrm{His}^{261}, \mathrm{Tyr}^{253}$ ) that have been identified in the primary structure. Fournal of Molecular Endocrinology (2001) 27, 77-83

\section{INTRODUCTION}

The human type I (placenta, skin, mammary gland, prostate, endometrium) and type II (gonads, adrenals) isoforms of $3 \beta$-hydroxysteroid dehydro- genase $(3 \beta-\mathrm{HSD}$, EC $1 \cdot 1 \cdot 1 \cdot 145) /$ steroid $\Delta^{5}-\Delta^{4}$ isomerase $(\mathrm{EC} 5 \cdot 3 \cdot 3 \cdot 1)(3 \beta-\mathrm{HSD} /$ isomerase) are encoded by two distinct genes, which are expressed in a tissue-specific pattern. In human placenta, type I $3 \beta-H S D /$ isomerase catalyzes the conversion of 
$3 \beta$-hydroxy-5-ene-steroids (dehydroepiandrosterone, pregnenolone) to 3-oxo-4-ene-steroids (androstenedione, progesterone) on a single, dimeric protein containing both enzyme activities (Thomas et al. 1989). Androstenedione (derived from fetal dehydroepiandrosterone) is converted by placental aromatase and type I 17 $\beta$-hydroxysteroid dehydrogenase to estradiol, which participates in the cascade of events that initiates labor in humans (Kacsoh 2000). The type I enzyme is also selectively expressed in human breast (Gingras et al. 1999), prostate (Geldof et al. 1995), colon and cervical (Gingras \& Simard 1999) tumors, where it catalyzes the first step in the conversion of circulating dehydroepiandrosterone to the growth-promoting hormone, estradiol or testosterone. Determination of the structure/function relationships of the type I enzyme by mutagenesis and crystallographic studies may lead to the development of specific inhibitors of type I $3 \beta-\mathrm{HSD} /$ isomerase that can control the timing of labor and slow the growth of hormone-sensitive tumors.

Two regions in the primary enzyme structure have been shown to be membrane-spanning domains in the human type I enzyme through the deletion of each segment followed by the subcellular localization of each protein after baculoviral expression in insect Sf9 cells. One hydrophobic segment lies in the $\mathrm{NH}_{2}$-terminal region (residues 72-89), and the other segment is in the $\mathrm{COOH}$-terminal region (residues 283-310) of the human type I and type II 3ß-HSD/isomerase (Thomas et al. 1999). Homologous hydrophobic domains have been identified in 15 deduced proteins from the $3 \beta-\mathrm{HSD}$ gene family in several species (Simard et al. 1996).

Whereas the deletion of the $\mathrm{NH}_{2}$-terminal hydrophobic region (residues 72-89) produced a partially soluble protein with significantly reduced enzyme activities, the deletion of the $\mathrm{COOH}$ terminal hydrophobic domain (residues 283-310) produced a fully active cytosolic form of the enzyme that possessed $3 \beta-\mathrm{HSD}$ and isomerase activities comparable with those of the wild-type enzyme (Thomas et al. 1999). The presence of the detergents needed to solubilize the wild-type enzyme from microsomes and mitochondria (Thomas et al. 1989, Zhou et al. 1996) may have prevented the crystallization and structural analysis of this important steroidogenic enzyme. The development of an active, cytosolic form of the enzyme that can be purified without using detergents provides a useful tool for crystallographic studies. A similar approach was used to crystallize mandelate dehydrogenase after deletion of the membrane-binding region in that protein $(\mathrm{Xu} \&$ Mitra 1999). As described in the current report, we have purified the mutant form of human type I $3 \beta$-HSD/isomerase which lacks the 283-310 domain, compared the kinetics of substrate and cofactor utilization of the purified mutant and wild-type enzymes and obtained crystals of the purified, cytosolic $3 \beta-\mathrm{HSD} /$ isomerase.

\section{MATERIALS AND METHODS}

\section{Materials}

Dehydroepiandrosterone and pyridine nucleotides were purchased from Sigma Chemical Co. (St Louis, MO, USA); 5-androstene-3,17-dione from Steraloids Inc. (Wilton, NH, USA); reagent grade salts, chemicals and analytical grade solvents from Fisher Scientific Co. (Pittsburg, PA, USA). Glass-distilled, deionized water was used for all aqueous solutions.

\section{Site-directed mutagenesis}

The codons were deleted for amino acids 283-310 in the cDNA encoding human type I $3 \beta-H S D /$ isomerase as previously described (Thomas et al. 1999). This truncated protein is referred to as the 283-310 deletion-mutant or the cytosolic enzyme in this report. The correct mutations were confirmed using a PCR-based dideoxynucleotide sequencing method (Thermo Sequenase kit; Amersham Life Science, Cleveland, OH, USA). In addition, the entire cDNA encoding the mutant protein was sequenced to confirm its integrity.

\section{Expression of the mutant enzyme and preparation of the cytosolic fraction}

The mutant $3 \beta$-HSD cDNA was introduced into baculovirus as previously described (Nash et al. 1994, Thomas et al. 1999). Baculoviral stock was added to $1.5 \times 10^{9} \mathrm{Sf} 9$ cells $(11)$ at a multiplicity of infection of 10 for expression of the 283-310 deletion-mutant enzyme. After expression for $68 \mathrm{~h}$ in suspension culture, the recombinant baculovirusinfected Sf9 cells (31 in 11 batches) were homogenized by a hand-held, fritted glass homogenizer in $50 \mathrm{ml} 0.01 \mathrm{M}$ potassium phosphate buffer, $\mathrm{pH} 7 \cdot 4$, containing a cocktail of protease inhibitors (Nash et al. 1994). The homogenate was centrifuged at $800 \mathrm{~g}$ for $30 \mathrm{~min}$ in a Beckman (Fullerton, CA, USA) L8-M ultracentrifuge to pellet cell debris and nuclei. The resulting supernatant was centrifuged at $110000 \mathrm{~g}$ to pellet the mitochondria and microsomes. The $110000 \mathrm{~g}$ supernatant contained the Sf9 cell cytosol. Protein 
concentrations were determined by the Coomassie Blue method using BSA as the standard (Bradford 1976).

\section{Purification of the cytosolic enzyme}

The cytosolic preparations from 31 of cells were pooled and purified by affinity chromatography $(2.5 \times 16.3 \mathrm{~cm}$ column $)$ using Cibacron Blue 1000 (Sigma). After washing with $0.02 \mathrm{M}$ potassium phosphate, $\mathrm{pH} 7 \cdot 5$ (3.6 column volumes), the enzyme was eluted using a linear gradient: $0.02 \mathrm{M}$ potassium phosphate, $\mathrm{pH} 7.5,0.50 \mathrm{M} \mathrm{NaCl}$, $0.28 \mathrm{mM} \mathrm{NAD}^{+}(1.25$ column volumes $)$ to $0.02 \mathrm{M}$ potassium phosphate, $\mathrm{pH} 7 \cdot 5,2 \cdot 0 \mathrm{M} \mathrm{NaCl}$, $1.12 \mathrm{mM} \mathrm{NAD}^{+}(1.25$ column volumes $)$. The fractions $(8.0 \mathrm{ml})$ containing the highest $3 \beta-\mathrm{HSD}$ activities were pooled followed by desalting and concentration using Centriplus and Microcon YM-30 filtration devices (Millipore Corporation, Bedford, MA, USA). This preparation was applied to a hydroxylapatite column $(1.5 \times 6.0 \mathrm{~cm})$ (Biogel HT; Bio-Rad Laboratories, Hercules, CA, USA) equilibrated with $0.02 \mathrm{M}$ potassium phosphate, pH 7.5, 0.1 mM EDTA. The Bio-Gel HT column was washed with $0.14 \mathrm{M}$ potassium phosphate buffer, $\mathrm{pH} 7 \cdot 5, \quad 0.1 \mathrm{mM}$ EDTA $(3.5$ column volumes), and the pure enzyme was eluted using a linear gradient of $0.14 \mathrm{M}-0.32 \mathrm{M}$ potassium phosphate buffer, $\mathrm{pH} 7 \cdot 5,0.1 \mathrm{mM}$ EDTA $(1.5$ column volumes/buffer). The purity of the final preparation was assessed by SDS-PAGE, $\mathrm{NH}_{2}$-terminal sequence analysis and measurement of the specific $3 \beta$-HSD/isomerase activities during the final column chromatography as previously described (Thomas et al. 1988, 1989).

\section{Enzyme assays}

Michaelis-Menten kinetic constants for the $3 \beta$ HSD substrate were determined for the purified cytosolic and wild-type I enzyme in incubations containing dehydroepiandrosterone $(2-20 \mu \mathrm{M})$, $\mathrm{NAD}^{+}(0.1 \mathrm{mM})$ and purified enzyme $(0.03 \mathrm{mg})$ at $22{ }^{\circ} \mathrm{C}$ in $0.02 \mathrm{M}$ potassium phosphate, $\mathrm{pH} 7 \cdot 4$. The slope of the initial linear increase in absorbance at $340 \mathrm{~nm}$ (due to NADH production) per unit time was used to determine $3 \beta$-HSD activity. Kinetic constants for the isomerase substrate were determined at $22{ }^{\circ} \mathrm{C}$ in incubations of 5 -androstene-3,17dione $(17-42 \mu \mathrm{M})$, NADH $(0.05 \mathrm{mM})$ and purified enzyme $(0.01 \mathrm{mg})$ in $0.02 \mathrm{M}$ potassium phosphate buffer, $\mathrm{pH} 7 \cdot 4$. Isomerase activity was measured by the initial absorbance increase at $241 \mathrm{~nm}$ (due to androstenedione formation) as a function of time. Blank assays (zero-enzyme, zero-substrate) ensured that specific isomerase activity was measured as opposed to non-enzymatic, 'spontaneous' isomerization (Thomas et al. 1988).

Kinetic constants for the $3 \beta$-HSD cofactor were determined for the purified cytosolic and wild-type I enzyme in incubations containing $\mathrm{NAD}^{+}(20-$ $100 \mu \mathrm{M})$, dehydroepiandrosterone $(50 \mu \mathrm{M})$ and purified enzyme $(0.03 \mathrm{mg})$ in $0.02 \mathrm{M}$ potassium phosphate, $\mathrm{pH} 7 \cdot 4$, at $22^{\circ} \mathrm{C}$ using the spectrophotometric assay at $340 \mathrm{~nm}$. Kinetic constants for the isomerase cofactor were determined in incubations of NADH $(3-15 \mu \mathrm{M}), \quad 5$-androstene-3,17-dione $(100 \mu \mathrm{M})$ and purified enzyme $(0.01 \mathrm{mg})$ in $0.02 \mathrm{M}$ potassium phosphate buffer, $\mathrm{pH} 7 \cdot 4$ at $22^{\circ} \mathrm{C}$ using the spectrophotometric assay at $241 \mathrm{~nm}$.

The $3 \beta$-HSD and isomerase activities were monitored in column fractions during the purification using the spectrophotometric assays described above with saturating substrate (dehydroepiandrosterone, $50 \mu \mathrm{M}$; 5-androstene-3,17-dione, $100 \mu \mathrm{M}$ ) and cofactor $\left(\mathrm{NAD}^{+}, 100 \mu \mathrm{M}\right.$; NADH, $\left.50 \mu \mathrm{M}\right)$ concentrations in incubations containing $0.04 \mathrm{mg}$ protein. Changes in absorbance were measured with a Varian (Sugar Land, TX, USA) Cary 219 recording spectrophotometer. The MichaelisMenten constants $\left(K_{\mathrm{m}}\right.$ and $\left.\mathrm{V}_{\max }\right)$ were calculated from Lineweaver-Burke $(1 / \mathrm{S}$ vs $1 / \mathrm{V})$ plots and verified by Hanes-Woolf ( $\mathrm{S}$ vs $\mathrm{S} / \mathrm{V}$ ) plots (Segel 1975).

\section{Crystallization studies}

The purified cytosolic enzyme $(5 \mathrm{mg})$ was dialyzed into $0.01 \mathrm{M}$ Tris- $\mathrm{HCl}$ buffer, $\mathrm{pH} 7 \cdot 4$, and concentrated to $7.2 \mathrm{mg}$ protein $/ \mathrm{ml}$ using the Centriplus and Microcon YM-30 filtration devices. Conditions were screened for crystal growth using Crystal Screen 2 and Crystal Screen Cryo kits (Hampton Research, Laguna Niguel, CA, USA). Hangingdrop $(1 \mu \mathrm{l}$ protein solution $/ 1 \mu \mathrm{l}$ kit reagent) vapor diffusion was carried out in four sealed, 24-well plates kept in a constant-temperature $\left(20^{\circ} \mathrm{C}\right)$ incubation chamber. Crystal growth was monitored using a stereomicroscope over 3 weeks.

\section{RESULTS}

\section{Purification of the cytosolic form of $3 \beta$-HSD/isomerase}

As shown in Table 1 , the $3 \beta$-HSD and isomerase activities of the 283-310 deletion mutant are each purified 26-fold following the affinity (Cibacron Blue) and hydroxylapatite chromatographies. SDSPAGE (Fig. 1) reveals a single protein band (silver-stained) for the purified cytosolic enzyme 
TABle 1. Purification of the cytosolic form of human type I $3 \beta$-HSD/isomerase. The $3 \beta$-HSD activity was determined by spectrophotometric assay at $340 \mathrm{~nm}$ in incubations of dehydroepiandrosterone $(50 \mu \mathrm{M}), \mathrm{NAD}^{+}$ $(100 \cdot 0 \mu \mathrm{M})$ and protein $(0.04 \mathrm{mg})$ in $0.02 \mathrm{M}$ potassium phosphate buffer, $\mathrm{pH} 7 \cdot 4$. The isomerase activity was measured by spectrophotometric assay at $241 \mathrm{~nm}$ in incubations of 5 -androstene-3,17-dione $(100 \mu \mathrm{M})$, NADH $(50.0 \mu \mathrm{M})$ and protein $(0.04 \mathrm{mg})$ in $0.02 \mathrm{M}$ potassium phosphate buffer, $\mathrm{pH} 7 \cdot 4$. The cell cytosol was the $110000 \mathrm{~g}$ supernatant from a homogenate of Sf9 cells (3.0 l suspension culture) that were infected for $72 \mathrm{~h}$ with the 283-310 deletion-mutant baculovirus. These data represent the typical result from three purification procedures

\begin{tabular}{|c|c|c|c|}
\hline & $\begin{array}{l}\text { Specific } \\
\text { 3ß-HSD } \\
\text { activity } \\
\text { (nmol/min } \\
\text { per } \mathrm{mg})\end{array}$ & $\begin{array}{l}\text { Specific } \\
\text { isomerase } \\
\text { activity } \\
(\mathrm{nmol} / \mathrm{min} \\
\text { per } \mathrm{mg})\end{array}$ & $\begin{array}{l}\text { Total } \\
\text { protein } \\
(\mathrm{mg})\end{array}$ \\
\hline \multicolumn{4}{|l|}{ Preparation } \\
\hline Sf9 homogenate & $2 \cdot 1$ & $24 \cdot 3$ & 954 \\
\hline Sf9 cytosol & $3 \cdot 8$ & $32 \cdot 6$ & 445 \\
\hline Cibacron Blue & $29 \cdot 2$ & 364 & $10 \cdot 4$ \\
\hline Hydroxylapatite & $52 \cdot 4$ & 622 & $6 \cdot 6$ \\
\hline
\end{tabular}

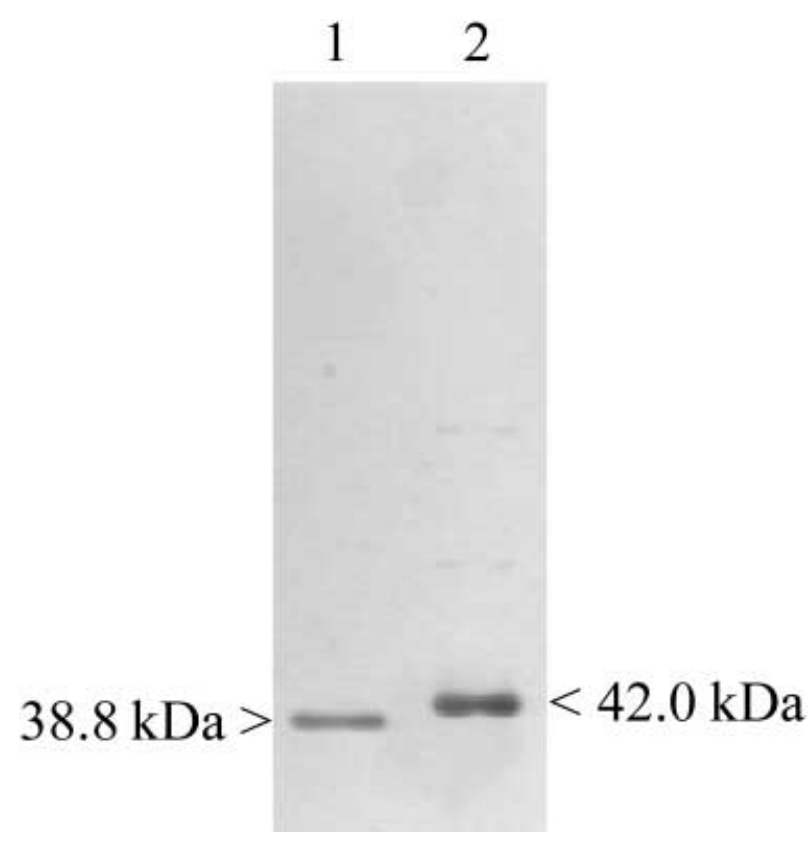

FIGURE 1. SDS-PAGE $(7 \cdot 5 \%)$ of the purified human cytosolic $3 \beta$-HSD/isomerase (lane 1 ) and wild-type I (lane 2) enzyme after hydroxylapatite chromatography. Each lane was over-loaded with $1.0 \mu \mathrm{g}$ protein, and bands visualized by silver staining. The deduced molecular masses of the enzymes, based on amino acid composition, are provided.
TABLE 2. Substrate kinetics for the $3 \beta-H S D$ and isomerase activities of the purified cytosolic and wild-type enzymes. Kinetic constants for the $3 \beta$-HSD substrate were determined in incubations containing dehydroepiandrosterone $(2-20 \mu \mathrm{M}), \mathrm{NAD}^{+}(0 \cdot 1 \mathrm{mM})$ and purified enzyme $(0.03 \mathrm{mg})$ in $0.02 \mathrm{M}$ potassium phosphate, $\mathrm{pH} 7 \cdot 4$. Kinetic constants for the isomerase substrate were determined in incubations of 5 -androstene-3,17-dione (17-42 $\mu \mathrm{M})$, NADH $(0 \cdot 05 \mathrm{mM})$ and purified enzyme $(0.01 \mathrm{mg})$ in $0.02 \mathrm{M}$ potassium phosphate buffer, $\mathrm{pH} 7 \cdot 4$

\begin{tabular}{|c|c|c|c|}
\hline \multicolumn{2}{|c|}{$3 \beta$-HSD } & \multicolumn{2}{|c|}{ Isomerase } \\
\hline $\begin{array}{l}K_{\mathrm{m}} \\
(\mu \mathrm{M})\end{array}$ & $\begin{array}{l}\mathrm{V}_{\max } \\
(\mathrm{nmol} / \mathrm{min} \\
\text { per } \mathrm{mg})\end{array}$ & $\begin{array}{l}K_{\mathrm{m}} \\
(\mu \mathrm{M})\end{array}$ & $\begin{array}{l}\mathrm{V}_{\max } \\
(\mathrm{nmol} / \mathrm{min} \\
\text { per } \mathrm{mg})\end{array}$ \\
\hline $4 \cdot 5$ & $52 \cdot 7$ & $25 \cdot 2$ & 576 \\
\hline $3 \cdot 7$ & $43 \cdot 3$ & $27 \cdot 9$ & 598 \\
\hline
\end{tabular}

and compares the monomeric molecular masses of the truncated soluble enzyme $(38.8 \mathrm{kDa})$ and wild-type I enzyme $(42 \cdot 0 \mathrm{kDa}) . \quad \mathrm{NH}_{2}$-terminal sequence analysis of the purified cytosolic enzyme detected a single protein with the expected sequence of the first nine amino acids: $\mathrm{NH}_{2}$-TGWSCLVTG. The enzyme eluted from the hydroxylapatite column with constant specific activities of $3 \beta-\mathrm{HSD}$ (mean \pm s.D. $=52.4 \pm 2.5 \mathrm{nmol} / \mathrm{min}$ per $\mathrm{mg}$ ) and isomerase $(622 \pm 29 \mathrm{nmol} / \mathrm{min}$ per $\mathrm{mg})$ over the four fractions that were pooled as the final preparation.

\section{Kinetic comparisons of the purified cytosolic and wild-type enzymes}

The Michaelis-Menten constants $\left(K_{\mathrm{m}}, \mathrm{V}_{\max }\right)$ measured for $3 \beta-H S D$ and isomerase substrate utilization are very similar for the 283-310 deletion-mutant and the wild-type I enzymes (Table 2). The kinetic constants determined for the oxidation of $\mathrm{NAD}^{+}$by the $3 \beta$-HSD activities and for the allosteric activation of the isomerase activity by NADH are almost identical for the two forms of the purified enzymes (Table 3 ).

\section{Crystallization of the cytosolic form of the enzyme}

Most of the hanging drops in the 96 vapor-diffusion wells using the two crystal screening kits had signs of protein precipitation after 2-3 days of incubation. In the well containing $0 \cdot 01 \mathrm{M}$ calcium chloride dihydrate, $0.05 \mathrm{M}$ sodium acetate trihydrate, $\mathrm{pH} 4 \cdot 6$, and $15 \%(\mathrm{w} / \mathrm{v})$ 2-methyl-2,4-pentanediol from the Crystal Screen Cryo kit, large needle 
TABLE 3. Cofactor kinetics for the $3 \beta$-HSD and isomerase activities of the purified cytosolic and wild-type enzymes. Kinetic constants for the $3 \beta$-HSD cofactor were determined in incubations containing $\mathrm{NAD}^{+}(20-100 \mu \mathrm{M})$, dehydroepiandrosterone $(50 \mu \mathrm{M})$ and purified enzyme $(0.03 \mathrm{mg})$ in $0.02 \mathrm{M}$ potassium phosphate, $\mathrm{pH} 7 \cdot 4$. Kinetic constants for the isomerase cofactor were determined in incubations of NADH (3-15 $\mu \mathrm{M})$, 5-androstene-3,17-dione $(100 \mu \mathrm{M})$, and purified enzyme $(0.01 \mathrm{mg})$ in $0.02 \mathrm{M}$ potassium phosphate buffer, $\mathrm{pH} 7 \cdot 4$

\begin{tabular}{|c|c|c|c|c|}
\hline & \multicolumn{2}{|c|}{ 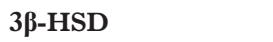 } & \multicolumn{2}{|c|}{ Isomerase } \\
\hline & $\begin{array}{l}K_{\mathrm{m}} \\
(\mu \mathrm{M})\end{array}$ & $\begin{array}{l}\mathrm{V}_{\max } \\
(\mathrm{nmol} / \mathrm{min} \\
\text { per } \mathrm{mg})\end{array}$ & $\begin{array}{l}K_{\mathrm{m}} \\
(\mu \mathrm{M})\end{array}$ & $\begin{array}{l}\mathrm{V}_{\max } \\
(\mathrm{nmol} / \mathrm{min} \\
\text { per } \mathrm{mg})\end{array}$ \\
\hline \multicolumn{5}{|l|}{$\begin{array}{l}\text { Purified } \\
\text { enzyme }\end{array}$} \\
\hline Cytosolic & $35 \cdot 3$ & $50 \cdot 9$ & $4 \cdot 6$ & 538 \\
\hline Wild-type & $34 \cdot 1$ & 45.9 & $4 \cdot 6$ & 536 \\
\hline
\end{tabular}

crystals grew over a 2 week period (Fig. 2). These crystals were fragile and broke easily after touching with a probe. The crystals stained positively with Coomassie Blue reagent. These tests confirm that the crystals are protein. Cuboidal salt crystals that were present in a few of the other wells failed both of these tests. The fragility of the needle crystals precluded washing and assaying for enzyme activity as well as the collection of X-ray diffraction data.

\section{DISCUSSION}

The wild-type I $3 \beta$-HSD/isomerase resides in the endoplasmic reticulum (microsomes) and mitochondria of human placental syncytiotrophoblast and of insect Sf9 cells infected with the recombinant baculovirus (Thomas et al. 1989, 1999). It is necessary to solubilize the enzyme from the microsomes or mitochondria using sodium cholate as the first step in purification ('Thomas et al. 1988, 1989, Zhou et al. 1996). The non-ionic polyoxyethylene detergent, Emulgen 913 (Kao Corp., Tokyo, Japan), must be included in the buffers during the purification, and removal of this detergent from the purified preparation results in the amorphous precipitation of inactive enzyme protein ('Thomas et al. 1999). The dependence on these detergents for solubility is most likely the reason that purified $3 \beta$-HSD/isomerase has not been successfully crystallized. The deletion of amino acid residues 283-310 in the COOH-terminal hydrophobic domain of $3 \beta-\mathrm{HSD} /$ isomerase produces a mutant enzyme that is cytosolic and yet retains the full $3 \beta$-HSD and isomerase activities (Thomas et al. 1999). These studies have opened the doors to the crystallization and structural analysis of the protein. However, the cytosolic protein must be purified to homogeneity and characterized kinetically to test whether the engineered, soluble form of the enzyme is a good model

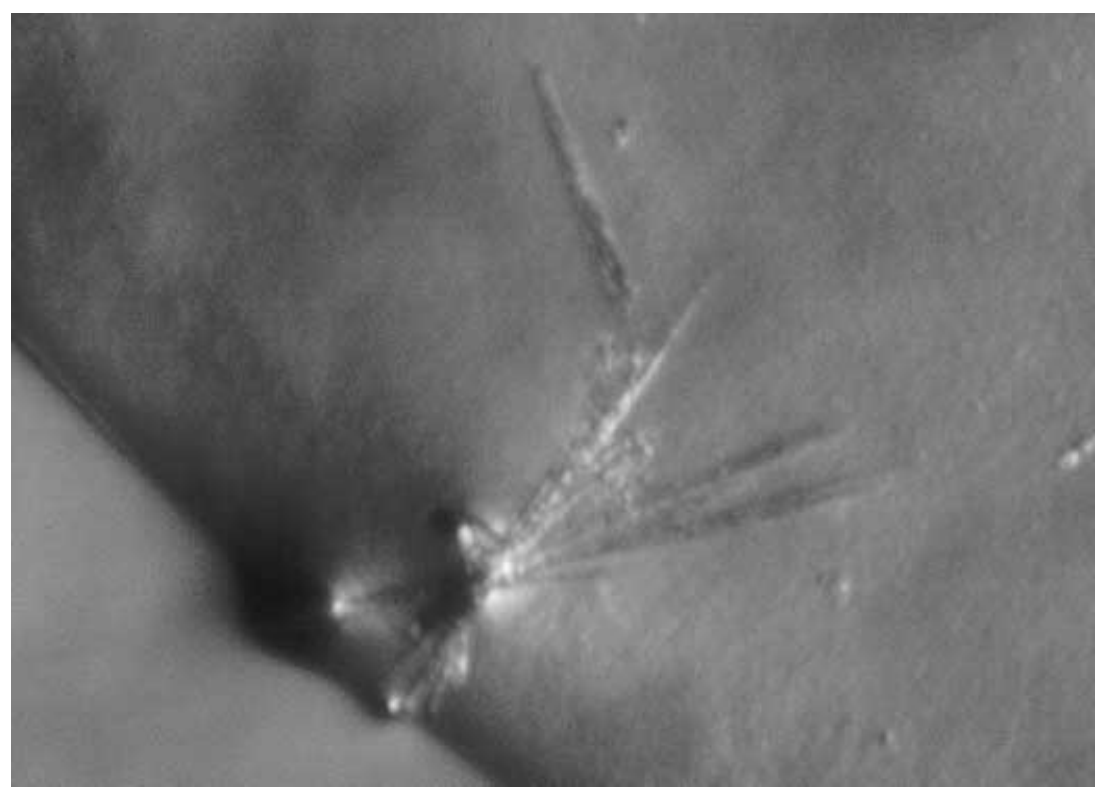

FIGURE 2. Needle crystals $(0 \cdot 3 \mathrm{~mm}$ length) of the purified human cytosolic $3 \beta$-HSD/isomerase in a hanging drop containing $0 \cdot 01 \mathrm{M}$ calcium chloride dihydrate, $0.05 \mathrm{M}$ sodium acetate trihydrate, $\mathrm{pH} 4.6$ and $15 \%(\mathrm{w} / \mathrm{v})$

2-methyl-2,4-pentanediol. 
for the wild-type enzyme in studies of tertiary structure and function. Finally, screening for crystal growth is the ultimate test of whether this approach can produce enzyme crystals.

For the cytosolic form of the enzyme, the initial diethylaminoethyl cellulose (DEAE) chromatography with detergent-based elution of the wild-type enzyme (Thomas et al. 1988, 1989) has been replaced with affinity chromatography using the Cibacron Blue gel, which binds to the nucleotide cofactor site of the enzyme. The enzyme is eluted from the affinity column using a gradient of $\mathrm{NAD}^{+}$and $\mathrm{NaCl}$ in the absence of detergent. Affinity chromatography produced a greater purification (15-fold) and yield $(3.5 \mathrm{mg} / 1$ Sf9 cell suspension) of the cytosolic enzyme compared with the purification ( 8 -fold) of the wild-type enzyme by DEAE chromatography $(2.4 \mathrm{mg} / \mathrm{l}$ yield).

Although hydroxylapatite chromatography is the second step in the purification of both the wild-type and cytosolic enzymes, the 283-310 deletion-mutant is free of detergent and requires different elution conditions. When the same gradient that successfully purified the detergent-solubilized, wild-type enzyme was used to elute the mutant enzyme, the purity of the eluted cytosolic protein was unacceptable. By increasing the concentration of phosphate salt used in the pre-gradient wash and using a higher linear phosphate gradient for elution $(0.05-0.25 \mathrm{M}$ for wild-type; $0 \cdot 14-0.32 \mathrm{M}$ for the soluble form), the 283-310 deletion-mutant enzyme was purified to homogeneity according to SDS-PAGE, $\mathrm{NH}_{2}$ terminal sequence analysis and elution from the hydroxylapatite column at constant specific enzyme activities. The yield of pure enzyme was greater for the cytosolic enzyme $(2 \cdot 2 \mathrm{mg} / 1 \mathrm{Sf} 9$ cell suspension) compared with the wild-type enzyme $(1.0 \mathrm{mg} / \mathrm{l})$.

Based on the results of Michaelis-Menten kinetic analysis for both substrate and cofactor utilization, the maximal specific $3 \beta-H S D$ activities $\left(\mathrm{V}_{\max }\right.$ values) measured for the final purified preparations of the cytosolic and wild-type enzyme enzymes are almost identical, as are the maximal isomerase activities of the two forms of enzyme (Tables 2 and $3)$. Furthermore, the concentrations of substrate and cofactor required to achieve one-half of the maximal $3 \beta$-HSD and isomerase activities $\left(K_{\mathrm{m}}\right.$ values) are remarkably similar. These equivalent kinetic constants determined with pure enzyme from each source suggest that the cytosolic mutant and wild-type proteins have similar tertiary structures.

Preparation of the purified cytosolic enzyme for crystallization trials by extensive dialysis and concentration produced a fully active, supersaturated enzyme preparation in an appropriate buffer.
This preparation yielded needle crystals of enzyme protein during trials using only two standard crystal screening kits. The rapid production of protein crystals using the purified cytosolic form of human type I $3 \beta-H S D /$ isomerase provides direct evidence that this is a viable approach to overcome the difficulties of obtaining crystallographic data on this important steroidogenic enzyme. Although the needle crystals obtained in this study were not appropriate for the collection of $\mathrm{X}$-ray diffraction data, the creation and purification of a fully active form of the enzyme that is amenable to crystallization is a significant advance toward the goal of determining the structure/function relationships of $3 \beta$-HSD/isomerase.

Crystallographic studies of the enzyme will clarify why the deletion of the 283-310 hydrophobic domain induces no change in enzyme function despite being adjacent to the putative active site $\left(\mathrm{Tyr}^{253}, \mathrm{His}^{261}\right)$ in the primary structure (Mason et al. 1998, Thomas et al. 1998), whereas deletion of the 72-89 hydrophobic domain destroys enzyme activity (Thomas et al. 1999). It is likely that the 283-310 domain functions solely as a membraneanchor that is not involved in the tertiary structure of the active-site region.

\section{ACKNOWLEDGEMENTS}

We thank Dr F Scott Mathews, Department of Biochemistry and Molecular Biophysics, Washington University School of Medicine, St Louis, Missouri, USA, for valuable discussions and for access to the equipment used in the growth of the enzyme crystals. This work was supported by NIH Grant No. HD20055 (J L T).

\section{REFERENCES}

Bradford MM 1976 A rapid and sensitive method for the quantitation of microgram quantities of protein utilizing the principle of protein-dye binding. Analytical Biochemistry $\mathbf{7 2}$ $248-254$

Geldof AA, Dijkstra I, Newling DW \& Rao BR 1995 Inhibition of 3-beta-hydroxysteroid dehydrogenase: an approach for prostate cancer treatment? Anticancer Research 15 1349-1354.

Gingras S \& Simard J 1999 Induction of 3ß-hydroxysteroid dehydrogenase/isomerase type 1 expression by interleukin- 4 in human normal prostate epithelial cells, immortalized keratinocytes, colon, and cervix cancer cell lines. Endocrinology 140 4573-4584.

Gingras S, Moriggi R, Groner B \& Simard J 1999 Induction of $3 \beta$-hydroxysteroid dehydrogenase $/ \Delta^{5}-\Delta^{4}$ isomerase type 1 gene transcription in human breast cancer cell lines and in normal mammary epithelial cells by interleukin-4 and interleukin-13. Molecular Endocrinology 13 66-81. 
Kacsoh B 2000 Reproductive endocrinology. In Endocrine Physiology, pp 559-560. New York: McGraw-Hill Companies, Inc.

Mason JI, Naville D, Evans BW \& Thomas JL 1998 Functional activity of $3 \beta$-hydroxysteroid dehydrogenase/ isomerase. Endocrine Research 24 549-557.

Nash WE, Mercer RW, Blanco G, Strickler RC, Mason JI \& Thomas JL 1994 Over-expression of human type I (placental) 3 $\beta$-hydroxy-5-ene-steroid dehydrogenase/ isomerase in insect cells infected with recombinant baculovirus. Fournal of Steroid Biochemistry and Molecular Biology 50 235-240.

Segel IH 1975 Enzyme Kinetics, pp 47, 211. New York: John Wiley \& Sons.

Simard J, Durocher F, Mebarke F, Turgeon C, Sanchez R, Labrie Y, Couet J, Trudel C, Rheaume E, Morel Y, Luu-The V \& Labrie F 1996 Molecular biology and genetics of the $3 \beta$-hydroxysteroid dehydrogenase $/ \Delta^{5}-\Delta^{4}$ isomerase gene family. Fournal of Endocrinology 150 S189-S207.

Thomas JL, Berko EA, Faustino A, Myers RP \& Strickler RC 1988 Human placental 3 $\beta$-hydroxy-5-ene-steroid dehydrogenase and steroid 5-4-ene-isomerase: purification from microsomes, substrate kinetics and inhibition by product steroids. Fournal of Steroid Biochemistry 31 785-793.

Thomas JL, Myers RP \& Strickler RC 1989 Human placental $3 \beta$-hydroxy-5-ene-steroid dehydrogenase and steroid 5-4-ene-isomerase: purification from mitochondria and kinetic profiles, biophysical characterization of the purified mitochondrial and microsomal enzymes. Fournal of Steroid Biochemistry 33 209-217.

Thomas JL, Evans BW, Blanco G, Mercer RW, Mason JI, Adler S, Nash WE, Isenberg KE \& Strickler RC 1998 Site-directed mutagenesis identifies amino acid residues associated with the dehydrogenase and isomerase activities of human type I (placental) 3ß-hydroxysteroid dehydrogenase/ isomerase. Fournal of Steroid Biochemistry and Molecular Biology 66 327-334.

Thomas JL, Evans BW, Blanco G, Mason JI \& Strickler RC 1999 Creation of a fully active, cytosolic form of human type I $3 \beta$-hydroxysteroid dehydrogenase/isomerase by the deletion of a membrane-spanning domain. Fournal of Molecular Endocrinology 23 231-239.

Xu Y \& Mitra B 1999 A highly active, soluble mutant of the membrane-associated (S)-mandelate dehydrogenase from Pseudomonas putida. Biochemistry 38 12367-12376.

Zhou M, Breton R, Azzi A \& Lin S-X 1996 Rapid purification of the over-expressed membrane $3 \beta$-hydroxysteroid dehydrogenase in the presence of detergents. Fournal of Crystal Growth 168 142-149.

RECEIVED 10 January 2001

ACCEPTED 30 March 2001 